\title{
|lsolation and characterization of novel bacteriophages as a potential therapeutic option for Escherichia coli urinary tract infections
}

\author{
Edgar González-Villalobos 1,2,3,4 • Rosa María Ribas-Aparicio ${ }^{1}$ • Gerardo Erbey Rodea Montealegre 2,3 . \\ Laura Belmont-Monroy ${ }^{1,2,3}$ - Yerisaidy Ortega-García ${ }^{1,2,3}$. Gerardo Aparicio-Ozores ${ }^{1}$ • José Luis Balcázar ${ }^{4,5}$. \\ Carlos Alberto Eslava-Campos ${ }^{2,3} \cdot$ Ulises Hernández-Chiñas ${ }^{2,3} \cdot$ José Molina-López $^{2,3}$ (i)
}

Received: 8 February 2021 / Revised: 27 May 2021 / Accepted: 25 June 2021 / Published online: 12 July 2021

(C) The Author(s) 2021

\begin{abstract}
Urinary tract infections (UTIs) are mainly caused by uropathogenic Escherichia coli (UPEC), whose impact can be exacerbated by multidrug-resistant (MDR) strains. Effective control strategies are, therefore, urgently needed. Among them, phage therapy represents a suitable alternative. Here, we describe the isolation and characterization of novel phages from wastewater samples, as well as their lytic activity against biofilm and adherence of UPEC to HEp-2 cells. The results demonstrated that phage vB_EcoMphiEc1 ( $\phi E \mathrm{E} 1)$ belongs to Myoviridae family, whereas vB_EcoS-phiEc3 $(\phi E \mathrm{Ec} 3)$ and vB_EcoS-phiEc4 $(\phi E \mathrm{E} 4)$ belong to Siphoviridae family. Phages showed lytic activity against UPEC and gut commensal strains. Phage $\phi \mathrm{Ec} 1$ lysed UPEC serogroups, whereas phages $\phi E \mathrm{Ec} 3$ and $\phi E \mathrm{E} 4$ lysed only UTI strains with higher prevalence toward the O25 serogroup. Moreover, phages $\phi \mathrm{Ec} 1$ and $\phi \mathrm{Ec} 3$ decreased both biofilm formation and adherence, whereas $\phi \mathrm{Ec} 4$ was able to decrease adherence but not biofilm formation. In conclusion, these novel phages showed the ability to decrease biofilm and bacterial adherence, making them promising candidates for effective adjuvant treatment against UTIs caused by MDR UPEC strains.
\end{abstract}

\section{Key points}

- Phage with lytic activity against MDR UPEC strains were isolated and characterized under in vitro conditions.

- A novel method was proposed to evaluate phage activity against bacterial adherence in HEp-2 cell.

- Phages represent a suitable strategy to control infections caused by MDR bacteria.

Keywords Adherence $\cdot$ Biofilm $\cdot$ Multidrug resistance $\cdot$ Phage therapy $\cdot$ Urinary tract infections

José Molina-López

joseml@unam.mx

1 Departamento de Microbiología, Escuela Nacional de Ciencias Biológicas (ENCB), Instituto Politécnico Nacional (IPN), Prolongación de Carpio y Plan de Ayala s/n, Colonia Santo Tomás, C.P. 11340 Mexico City, Mexico

2 Unidad Periférica de Investigación Básica y Clínica en Enfermedades Infecciosas, Departamento de Salud Pública/División de Investigación, Facultad de Medicina, UNAM, C.P. 04510 Mexico City, Mexico

3 Laboratorio de Patogenicidad Bacteriana, Unidad de Hemato-Oncología e Investigación, Hospital Infantil de México Federico Gómez/Facultad de Medicina, UNAM, Dr. Márquez 162 Col. Doctores. Alcaldía Cuauhtémoc, C.P. 06720 Mexico City, Mexico

4 Catalan Institute for Water Research (ICRA), 17003 Girona, Spain

5 University of Girona, 17004 Girona, Spain

\section{Introduction}

Urinary tract infections (UTIs) are one of the most common health problems, affecting 150 million of people each year worldwide (Tamadonfar et al. 2019). In 2007, there were an estimated 10.5 million ambulatory visits for UTI symptoms and 2-3 million emergency department visits in the USA (Foxman 2010, 2014), reaching a cost of more than USD 6 billion on its control and treatment (Mann et al. 2017). Community-acquired UTI is the most frequent infection, whose main etiological agent is Escherichia coli. UTIs are usually caused by uropathogenic E. coli (UPEC), with frequencies around $95 \%$ for community-acquired and $80 \%$ for uncomplicated UTIs in both inpatients and outpatients (Kot 2019). Among them, UPEC serogroups O1, O2, O4, O6, O7, $\mathrm{O} 8, \mathrm{O} 15, \mathrm{O} 16, \mathrm{O} 18, \mathrm{O} 21, \mathrm{O} 22, \mathrm{O} 25,075$, and $\mathrm{O} 83$ have been associated more frequently with UTIs (Li et al. 2010). 
UPEC pathogenesis includes two main phases: bacterial adherence to urogenital epithelium and biofilm production. In the first phase, UPEC binds to glycosylated surface proteins (uroplakins) using type 1 fimbriae. This binding leads to invasion of bladder epithelial cells by UPEC, which can escape into the cytoplasm and form intracellular bacterial communities (IBCs) (Terlizzi et al. 2017). In the second phase, biofilmproducing microorganisms such as UPEC show high resistance to antibiotics, preventing the arrival of antibiotics at the target site. Additionally, biofilm formation allows bacteria to resist the normal urine flow, favoring persistence in the urinary tract (Subaschandrabose and Mobley 2015; Magana et al. 2018). Biofilm production also enhances multidrugresistance (MDR) phenomenon (Hall and Mah 2017; Karigoudar et al. 2019). MDR pathogenic bacteria are a growing global problem that represents a large clinical and public health burden, as the number of emerging bacterial pathogens resistant to available antibiotics rapidly increases. In fact, the World Health Organization has recently listed UPEC as a critical priority pathogen (Tacconelli and Magrini 2020).

The global emergence of MDR pathogenic bacteria is driving the need for research into effective therapeutic antimicrobial alternatives. Bacteriophage therapy represents a promising alternative to antibiotics, which is based on the bactericidal activity of phages (Gordillo-Altamirano and Barr 2019). Phages recognize receptors on the bacterial surface with high specificity, inject their genetic material, multiply and assemble inside the bacterium, to finally break it and release their progeny to infect new bacteria (Jamal et al. 2019). The worldwide antibiotic crisis has led to a renewed interest in phage therapy. Phages with strong lytic activity against bacterial pathogens can be isolated from the environment. In addition, phages have the capacity to rapidly overcome bacterial resistance, which will inevitably emerge (Principi et al. 2019).

Given the clinical importance of UTIs, the aim of this work was to identify new phages with lytic features against UPEC. Here, we report an analysis of the characteristics of three phages isolated from wastewater samples in Mexico City (Mexico), considering both the ability to eliminate bacteria adhered to HEp-2 cells and decrease biofilm formation and their lytic activity against UPEC strains causing acute and persistent UTIs.

\section{Methods}

\section{Bacterial isolates}

One hundred fifty MDR E. coli isolates, previously serotyped and characterized by MDR patterns, were used in this study (Ahumada-Cota et al. 2020). The strains were initially grouped according to their origin: 50 strains isolated from stool cultures, 50 strains from recurrent UTIs at the
"Federico Gómez" Children's Hospital (Mexico City), and 50 strains from acute UTIs at the Family Medicine Unit No. 61 of the Mexican Social Security Institute (IMSS). All strains are available in our collection, which belongs to the World Data Centre for Microorganisms (WDCM 449).

\section{Bacterial biofilm production}

Each $E$. coli isolates was screened for biofilm formation using a 24-well plate assay, as previously described (Chibeu et al. 2012). Briefly, E. coli isolates were inoculated in $3 \mathrm{~mL}$ of Luria-Bertani (LB) broth and incubated at $37{ }^{\circ} \mathrm{C}$ for $18 \mathrm{~h}$. Immediately after, bacterial suspensions were adjusted to 1.5 $\times 10^{8} \mathrm{CFU} \mathrm{mL} \mathrm{m}^{-1}$, ten-fold diluted using minimum essential medium (MEM) supplemented with $1 \%$ glucose, and $450 \mu \mathrm{L}$ of this suspension was added into a 24 -well plate (Corning Inc., Corning, NY, USA). The plate was incubated at $37{ }^{\circ} \mathrm{C}$ for $24 \mathrm{~h}$ without agitation. After the incubation period, the plate was washed twice with $1 \times$ PBS to remove free bacteria, $1 \%$ crystal violet $(\mathrm{w} / \mathrm{v})$ was then added to stain the biofilm mass and incubated at room temperature for $15 \mathrm{~min}$. Crystal violet was removed by two washes with deionized water; the plates were dried at room temperature for $10 \mathrm{~min}$, and stained biofilm was solubilized with the addition of $200 \mu \mathrm{L}$ ethanol $96 \%(\mathrm{w} / \mathrm{v})$. The absorbance was then measured at an optical density of $590 \mathrm{~nm}$ using an Epoch microplate reader (BioTek, Winooski, VT, USA). The results were obtained by taking the average from three replicates in three independent assays. $E$. coli $\mathrm{K}-12$ and E. coli 49766 were used as negative and positive controls, respectively. The strains were classified as weak, moderate, and strong biofilm producers, according to Stepanović et al. 2007.

\section{Assays of bacterial adherence in HEp-2 cells}

HEp-2 cells were grown in a 24-well tissue culture plate on circular 13-mm glass coverslips in MEM without fetal bovine serum, until an 80-90\% confluence was obtained. The tested strains were grown overnight in tryptone water with $1 \%$ Dmannose to inhibit type 1 fimbriae-mediated attachment, and $1 \times 10^{7} \mathrm{CFU} \mathrm{mL}{ }^{-1}$ of this culture was then added into each well. The plates were incubated at $37^{\circ} \mathrm{C}$ with $5 \% \mathrm{CO}_{2}$ for $3 \mathrm{~h}$. At the end of infection, cells were washed three times with $1 \times$ PBS and fixed with methanol for 15 min, stained with $1 \%$ Giemsa for $20 \mathrm{~min}$, and examined under optical microscope (Mathewson and Cravioto 1989). E. coli K-12 and E. coli 49766 were used as negative and positive controls, respectively, and the adhered bacteria were counted microscopically in at least 15 fields. 


\section{Phage isolation}

Six wastewater samples were collected from Mexico City, which were centrifuged, and the supernatant filtered through $0.22-\mu \mathrm{m}$ pore-size to remove any bacteria present in the samples. These filtered samples were used to isolate phages, in which $500 \mu \mathrm{L}$ of each was added to a mid-log phase of different $E$. coli strains (E. coli K-12, E. coli ATCC 25922, E. coli CFT073 and two MDR E. coli isolates from UTI). The infected culture was incubated at $37^{\circ} \mathrm{C}$ with shaking for $24 \mathrm{~h}$ and then tested for plaque formation using the double-layer agar method, as previously described (Kropinsky et al. 2009). Lytic plaques were selected and isolated for propagation and further evaluation. These phages have been deposited and are available in our collection, which belongs to the World Data Centre for Microorganisms (WDCM 449).

\section{Phage purification}

Only three phages were selected and propagated in the mid$\log$ phase of the permissive strain. Cell debris and non-lysed cells were then removed by centrifugation at $10,000 \mathrm{~g}$ for $20 \mathrm{~min}$ and the supernatant was filtered through $0.22-\mu \mathrm{m}$ pore-size filter, which was recovered and incubated at $37^{\circ} \mathrm{C}$ in presence of RNase and DNase $\left(1 \mu \mathrm{g} \mathrm{mL}^{-1}\right.$ and $2 \mathrm{U}$, respectively) for $30 \mathrm{~min}$ to remove any residual bacterial DNA, as previously suggested (Zhao et al. 2019). $\mathrm{NaCl}$ was then added to reach $1 \mathrm{M}$, mixed, incubated at $4{ }^{\circ} \mathrm{C}$ for $1 \mathrm{~h}$, and subsequently centrifuged at $10,000 \mathrm{~g}$ for $20 \mathrm{~min}$. The supernatant was recovered and PEG 8000 was added $(10 \% ;[\mathrm{w} / \mathrm{v}])$ and incubated overnight at $4{ }^{\circ} \mathrm{C}$, followed by a chloroform extraction. The aqueous phase was ultracentrifuged at $500,000 \mathrm{~g}$ for $2 \mathrm{~h}$ using a caesium chloride density gradient, and the recovered fraction was dialyzed with deionized water (Sambrook and Russell 2001). The phage particles were quantified using the small drop plaque assay, as previously described (Mazzocco et al. 2009).

\section{Phage morphology}

A volume of $10 \mu \mathrm{L}$ of a purified phage suspension $\left(1 \times 10^{8}\right.$ PFU mL ${ }^{-1}$ ) was placed on a Formvar-carbon coated grid for 2 min, which were negative-stained with $5 \mu \mathrm{L}$ of $1 \%$ phosphotungstic acid for $2 \mathrm{~min}$ (Hans 2009), and the morphology was visualized under a JEM-1010 transmission electron microscope (JEOL; Tokyo, Japan) at the Central Laboratory for Microscopy Instrumentation, Escuela Nacional de Ciencias Biológicas, Instituto Politécnico Nacional.

\section{Isolation of genomic phage DNA}

Phage DNA was obtained from purified phage particles $(1 \times$ $10^{13} \mathrm{PFU} \mathrm{mL} \mathrm{m}^{-1}$ ), as previously described (Sambrook and
Russell 2001). Briefly, proteinase $\mathrm{K}$ (final concentration at $50 \mu \mathrm{g} \mathrm{mL}^{-1}$ ) and $10 \%$ SDS were added and incubated at 56 ${ }^{\circ} \mathrm{C}$ for $1 \mathrm{~h}$. DNA was then extracted with phenol:chloroform $(1: 1)$ and ethanol $\left(-70{ }^{\circ} \mathrm{C}\right)$ precipitation, resuspended in deionized water, and quantified spectrophotometrically using an Epoch microplate reader (BioTek). Later, $1 \mu \mathrm{g}$ of the purified DNA was digested with restriction enzymes such as $S s p \mathrm{I}, E c o \mathrm{RI}, E c o \mathrm{RV}$, and EcoRI-EcoRv (New England Biolabs, Ipswich, MA, USA), following manufacturer's recommendations. The products obtained were resolved by electrophoresis on $1 \%$ agarose gels.

\section{SDS-PAGE}

Proteins of selected phages were identified according to the procedure previously described (Boulanger 2009). Briefly, the phages were precipitated with $\mathrm{PEG} / \mathrm{NaCl}$, equal volumes of phage solution and $\mathrm{LiCl}(10 \mathrm{M})$ were mixed and incubated at $46{ }^{\circ} \mathrm{C}$ for $30 \mathrm{~min}$. DNase $(50 \mathrm{U})$ was added and incubated at $37^{\circ} \mathrm{C}$ for $2 \mathrm{~h}$. Phage particles were concentrated at $500,000 \mathrm{~g}$ at $4{ }^{\circ} \mathrm{C}$ for 30 min using a Sorvall ultra centrifuge. Concentrated phages were mixed with $2 \times$ Laemmli solution (65.8 mM Tris- $\mathrm{HCl}$ [pH 6.8], 2.1\% SDS, 26.3\% glycerol [w/v], $0.01 \%$ bromophenol blue and $100 \mathrm{mM} \beta$ mercaptoethanol) and heated at $100{ }^{\circ} \mathrm{C}$ for $10 \mathrm{~min}$. Proteins were then separated by $15 \%$ SDS-PAGE (polyacrylamidesodium dodecyl sulfate gel electrophoresis) and visualized using Coomassie blue or silver staining.

\section{Image analysis, spot excision, destaining, and drying}

Individually resolved bands were excised with an EXQuest Spot Cutter (Bio-Rad; Hercules, CA, USA) and processed following Bruker's standard protocol for in-gel protein digestion with minor modifications. Briefly, gel particles were washed three times with $50 \mathrm{mM} \mathrm{NH} \mathrm{NHCO}_{3}$ and $\mathrm{CH}_{3} \mathrm{CN}$ mixed in equal proportion. The proteins were reduced with $10 \mathrm{mM}$ DTT (at $56{ }^{\circ} \mathrm{C}$ for $45 \mathrm{~min}$ ) and alkylated with $55 \mathrm{mM} \mathrm{C}_{2} \mathrm{H}_{4} \mathrm{INO}$ (at room temperature in the dark for 20 min). Samples were then washed again with $50 \mathrm{mM}$ $\mathrm{NH}_{4} \mathrm{HCO}_{3}$ and $\mathrm{CH}_{3} \mathrm{CN}$, the supernatant was removed, and the gel particles were air-dried.

\section{Trypsin digestion, peptide extraction, and MALDI- TOF/TOF}

For digestion of the proteins, the gel particles were incubated with $25 \mathrm{ng} / \mathrm{L}$ trypsin gold (Promega; Madison, WI, USA) in $25 \mathrm{mM} \mathrm{NH}_{4} \mathrm{HCO}_{3}$ at $37^{\circ} \mathrm{C}$ overnight. The supernatants were recovered and stored at $-20^{\circ} \mathrm{C}$, whereas the gel particles were incubated a second time with $50 \mathrm{mM} \mathrm{NH}_{4} \mathrm{HCO}_{3}$ at $37^{\circ} \mathrm{C}$ overnight and the supernatants were then stored at $-20^{\circ} \mathrm{C}$. Peptides were extracted in $50 \mu \mathrm{L}$ trifluoroacetic acid $0.1 \%$ / 
acetonitrile (1:1) for $30 \mathrm{~min}$ at room temperature. All supernatants were mixed and dried in a vacuum centrifuge. Peptides were resuspended in trifluoroacetic acid and analyzed using a MALDI-TOF (MS/MS) Ultraflextreme mass spectrometer (Bruker; Billerica, MA, USA). An AnchorChip target and $\alpha$-cyano-4-hydroxycinnamic acid (HCCA) matrix were used, according to the manufacturer's instructions. The laser intensity was adjusted to $50 \%$ for the acquisition of masses, with three or four repetitions. For the analysis, spectra with $1 \times$ $10^{3}-1 \times 10^{4}$ intensity peaks were considered, and the identity of the protein was matched using the Mascot search engine with the following parameters: enzyme, trypsin; missed cleavages, 1; fixed modification, carbamidomethyl $\mathrm{C}$; variable modification, oxidation M; parent tolerance, 0.2 Da; fragment tolerance, $0.5 \mathrm{Da}$. Positive protein identifications were considered reliable with a Mascot score higher than 30 .

\section{Phage-host range assays}

The host range of isolated phages was performed according to the previously described spot test (Kutter 2009). Briefly, each E. coli isolate was grown until the mid-log phase, and $200 \mu \mathrm{L}$ were mixed with $3 \mathrm{~mL}$ molten agar and poured on LB plates. A spot of $10 \mu \mathrm{L}$ of each phage (final concentration at $1 \times 10^{6}$ PFU $\mathrm{mL}^{-1}$ ) was added and left dry, and the plates were then incubated at $37^{\circ} \mathrm{C}$ for $24 \mathrm{~h}$. Phage specificity was also tested on the following strains: Salmonella enterica subsp. enterica serovar Typhi ATCC 6539, Salmonella enterica subsp. enterica serovar Choleraesuis ATCC 10708, Salmonella enterica subsp. enterica serovar Typhimurium ATCC 14028, Pseudomonas aeruginosa ATCC 9027, and clinical isolates of Yersinia enterocolitica, Klebsiella pneumoniae, Shigella boydii, and Staphylococcus aureus, in which the spot test was used, as previously described (Mazzocco et al. 2009).

\section{Effect of the phages on biofilm}

Twenty-one biofilm-forming strains were selected based on their susceptibility to isolated phages and biofilm production. Briefly, $1 \times 10^{7} \mathrm{PFU} \mathrm{mL}^{-1}$ of the selected phage was added into biofilm, previously grown for $18 \mathrm{~h}$, and the plate was then incubated for $1 \mathrm{~h}$. After the incubation period, the plate was washed twice with $1 \times \mathrm{PBS}$, and the remaining biofilm was stained and evaluated, as previously described (Chibeu et al. 2012).

\section{Effect of the phage infection on bacterial adherence}

Eighteen isolates were selected based on phage susceptibility and adherence assay. We designed the adherence challenge at the end of conventional infection assay as follows: cells were washed with $1 \times$ PBS to remove any unattached bacteria, then 1 $\times 10^{6} \mathrm{PFU} \mathrm{mL} \mathrm{m}^{-1}$ of each phage was added to each well and the plates were incubated at $37{ }^{\circ} \mathrm{C}$ with $5 \% \mathrm{CO}_{2}$ for $2 \mathrm{~h}$. The remaining of the assay was completed as previously described (Mathewson and Cravioto 1989). The phages were recovered and quantified after assay, which were performed in duplicate. HEp-2 cell was also incubated with phages to discard damage on the monolayer.

\section{Statistical analyses}

All statistical analyses were performed using GraphPad Prism software version 8.00 (GraphPad Software Inc., San Diego, CA, USA). The effect of phages on biofilm was analyzed using the unpaired Student's $t$ test, whereas its effect on UPEC attached to HEp-2 cells was analyzed using analysis of variance (ANOVA). Differences were considered statistically significant at $P<0.05$.

\section{Results}

\section{Isolation and morphology of selected phages}

Phages were isolated from six different wastewater locations in Mexico City. Due to the plaque morphologies, only three phages were further characterized (data not shown), which were named vB_EcoM-phiEc1 ( $\phi E c 1)$, vB_EcoS-phiEc3 $(\phi E c 3)$, and $v B \_E c o S-p h i E c 4$ ( $\left.\phi E c 4\right)$, according to the current naming conventions (Adriaenssens and Brister 2017). Electron microscopy revealed different phage morphological features (Fig. 1). Phage $\phi \mathrm{Ec} 1$ showed an icosahedral head of $76 \mathrm{~nm}$ in diameter and a contractile tail of $126 \mathrm{~nm}$ in length (Fig. 1a), whereas phages $\phi E \mathrm{Ec} 3$ and $\phi E \mathrm{E} 4$ exhibited an icosahedral head of $60 \mathrm{~nm}$ in diameter and a long non-contractile tail with six fibers (Fig. $1 \mathrm{~b}$ and c).

\section{Lytic activity against UPEC and phage host-range}

Lytic activity of phages $\phi E \mathrm{Ec} 1, \phi \mathrm{Ec} 3$, and $\phi \mathrm{Ec} 4$ was tested against three groups of E. coli strains (acute UTI, recurrent UTI, and stool cultures) using the spot test. Phage $\phi E c 1$ showed the broadest host range, lysing 35/150 (23.3\%) strains. Among them, 18/35 (51.4\%) acute UTI strains, 10/ $35(28.5 \%)$ strains from stool cultures, and 7/35 (20\%) recurrent UTI strains exhibited susceptibility to phage $\phi E c 1$. Phage $\phi E c 3$ also showed the ability to lyse $18 / 150$ (12\%) strains, of which 7/18 (38.8\%) acute UTI strains were lysed, followed by $11 / 18(61.1 \%)$ strains belonging to recurrent UTI; however, no effect was detected against strains from stool cultures. Moreover, phage $\phi E \mathrm{E} 4$ showed the ability to lyse $12 / 150$ (8\%) strains, of which 7/12 (58.3\%) acute UTI strains were lysed, followed by 5/12 (41.6\%) recurrent UTI strains; however, phage $\phi \mathrm{Ec} 4$ did not lyse strains from stool cultures.

Additionally, the host range of phages $\phi \mathrm{Ec} 1, \phi \mathrm{Ec} 3$, and $\phi E c 4$ was tested against the following bacterial species: $S$. 


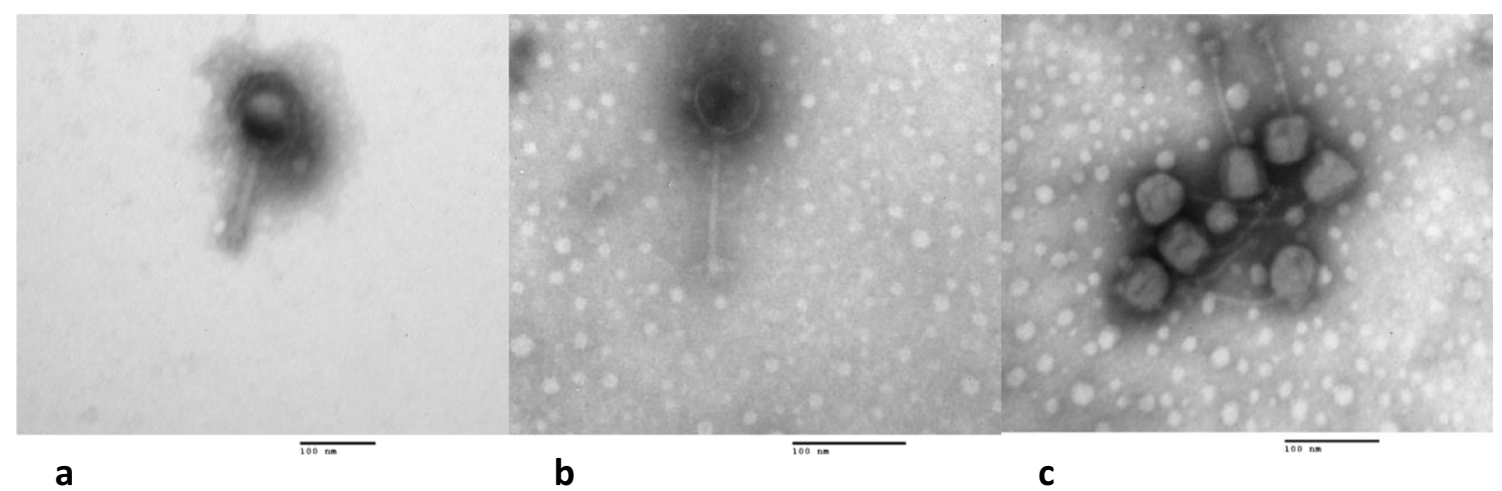

Fig. 1 Morphology of phages $\phi E c 1, \phi E c 3$ and $\phi E c 4$. Transmission electron micrographs of phages $\phi E c 1$ (a), $\phi \mathrm{Ec} 3$ (b), and $\phi \mathrm{Ec} 4$ (c)

enterica subsp. enterica serovar Typhi, S. enterica subsp. enterica serovar Choleraesuis, $S$. enterica subsp. enterica serovar Typhimurium, Pseudomonas aeruginosa, Yersinia enterocolitica, Klebsiella pneumoniae, Shigella boydii, Staphylococcus aureus, and Escherichia coli (ATCC 25966, K-12, CFT073, and 49766 strains). All tested strains were resistant to phages $\phi \mathrm{Ec} 1, \phi \mathrm{Ec} 3$, and $\phi \mathrm{Ec} 4$.

\section{Enzymatic analysis of selected phages}

Genomic differences were determined by DNA restriction, and total phage DNA was thus digested with $S s p \mathrm{I}, E c o$ RI, $E c o$ RV, and EcoRI-EcoRV (Fig. 2). Restriction with $S s p$ I showed differences among the three phages. Although all phages shared common fragments, the restriction pattern of phage $\phi E c 1$ was different than the remaining phages. Phage $\phi E c 3$ and $\phi E c 4$ shared a common pattern; however, phage $\phi E c 3$ possess 3 unique fragments (Fig. 2, lanes 1-3). Restriction with $E c o$ RI showed a unique pattern for phage $\phi E c 3$ (Fig. 2, lane 5), whereas restriction with EcoRV showed common fragments among them (Fig. 2, lanes 7, 8, 9). However, phage $\phi E c 3$ showed additional unique fragments (Fig. 2, lane 8). Although restriction patterns generated with $E c o$ RI-EcoRV revealed common fragments among them (Fig. 2 , lanes $10,11,12)$, phage $\phi E c 3$ showed additional unique fragments (Fig. 2, lane 11).

\section{Analysis of protein profiles}

To identify proteins, phage lysates were resolved on $15 \%$ SDS-PAGE gel electrophoresis. A protein of approximately $50 \mathrm{kDa}$ was detected in phage $\phi \mathrm{Ec} 1$ (data not shown), whereas two proteins were detected in phage $\phi \mathrm{Ec} 3$ (the first one has a molecular weight of approximately $36-37 \mathrm{kDa}$ and the second one of approximately $11 \mathrm{kDa})$. Two proteins were also detected in phage $\phi E c 4$ (one of $36-37 \mathrm{kDa}$ and another of approximately $13 \mathrm{kDa}$ ). Similar staining profiles were observed with Coomassie blue and silver staining (Fig. 3 and Fig. S1). The heavier protein was not size-related between $\phi \mathrm{Ec} 1$ and $\phi \mathrm{Ec} 3$ or $\phi \mathrm{Ec} 4$, nor the smaller protein between them. According to mass spectrometry data, the higher molecular weight (MW) proteins corresponded to RNA2 polyprotein and endolysin (Table S1), whereas the lower MW proteins showed an average of $25 \mathrm{~m} / \mathrm{z}$ peaks which did not show significant matches in Mascot.

\section{Bacterial biofilm production and effect of selected phages}

One hundred-fifty $E$. coli were examined for biofilm production, and only 48 (32\%) of the 150 isolates were biofilm producers. Predominant biofilm phenotype was weak, with 28 strains followed by 16 moderate and only 4 strong producers. The majority biofilm producer strains belonged to isolates
Fig. 2 Restriction analysis of genomic $\phi \mathrm{Ec} 1, \phi \mathrm{Ec} 3$, and $\phi \mathrm{Ec} 4$ DNA. Molecular-weight size marker (lane W). Total DNA of $\phi \mathrm{Ec} 1, \phi \mathrm{Ec} 3$, and $\phi \mathrm{Ec} 4$ digested with $S s p$ I (lanes 1-3), EcoRI (lanes 4-6), EcoRV (lanes 7-9), and EcoRI-EcoRV (lanes 10-12), respectively

\section{$\begin{array}{llllllllllllll}\text { W. } 1 & 2 & 3 & \text { W. } 4 & 5 & 6 & \text { W. } & 7 & 8 & 9 & \text { W. } 10 & 11 & 12 & \text { W. }\end{array}$}

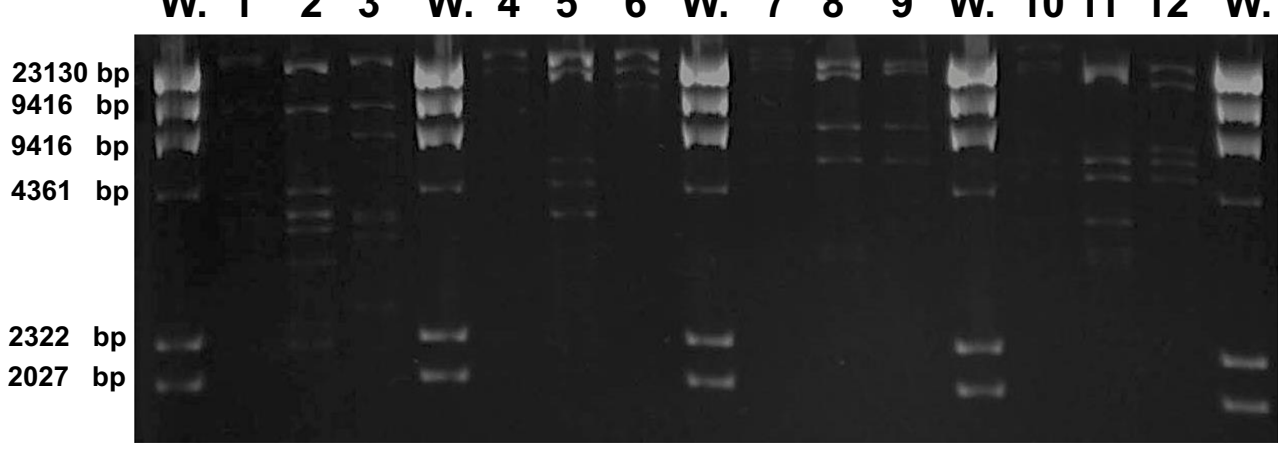




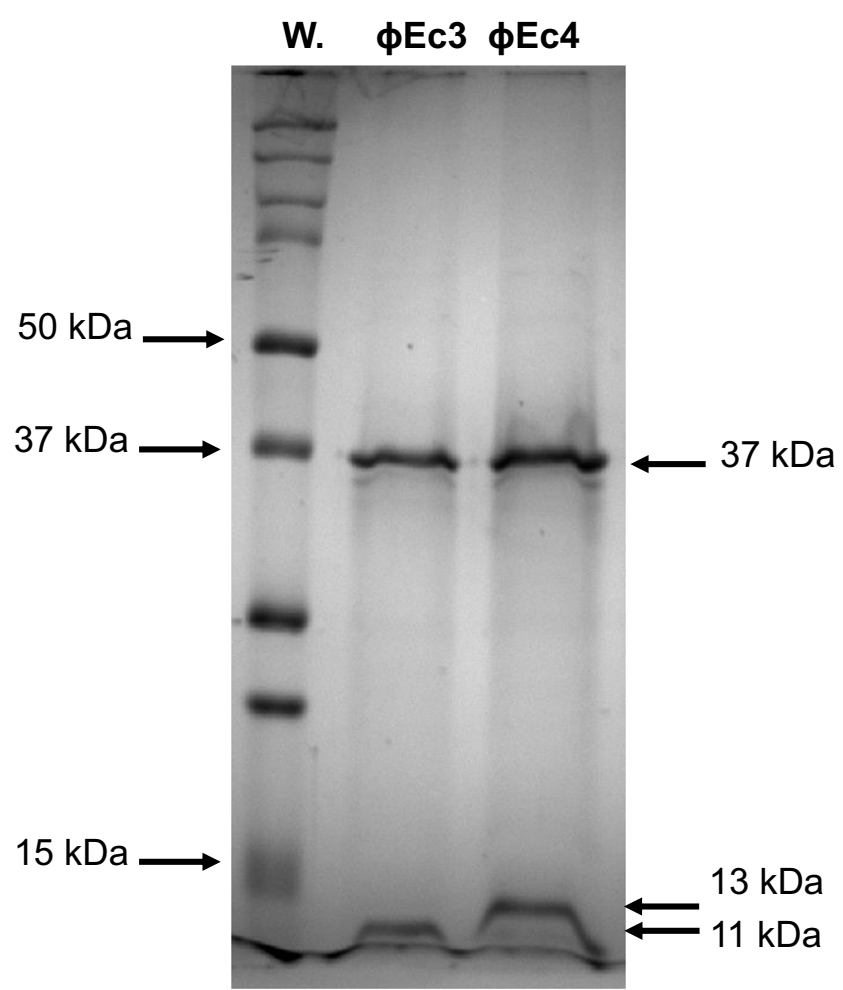

Fig. 3 Analysis of $\phi E c 3$ and $\phi E c 4$ protein profiles (15\% SDS-PAGE stained with Coomassie blue). $\phi E \mathrm{Ec} 3$, two proteins of $37 \mathrm{kDa}$ and $11 \mathrm{kDa}$ were identified. $\phi E \mathrm{E} 4$, two proteins of $37 \mathrm{kDa}$ and $13 \mathrm{kDa}$ were identified

from stool cultures 19 (12.7\%), followed by recurrent UTI with $15(10 \%)$, and finally acute UTI with $14(9.3 \%)$.

Twenty-one biofilm-forming strains were selected based on the phage susceptibility in order to analyze the effect of the isolated phages on them. Some of the selected strains were susceptible to at least one phage. In these cases, the strains were then tested with each of them. Phage $\phi E c 1$ decreased biofilm formation in 4/9 strains, but a statistical difference was only observed in two cases (Fig. 4). On the other hand, phage $\phi E c 3$ was able to decrease biofilm in $3 / 6$ of the strains tested (Fig. 4), whereas phage $\phi E c 4$ had no effect on biofilm formation (data not shown).

\section{Relationship between serogroup and phage susceptibility}

The isolated phages showed activity against strains from UPEC serogroups, as well as from non-UPEC serogroups (Table 1). Phage $\phi E c 1$ showed lytic activity against strains belonging to non-UPEC serogroups, whereas phages $\phi E c 3$ and $\phi E c 4$ showed lytic activity against bacteria belonging to UPEC serogroups, mostly of the O25 serogroup.

\section{Bacterial adherence in HEp-2 cells}

Eighty-three (55.3\%) strains were adherent to HEp-2 cells. Adherence frequencies were found to be very similar among the groups, with $20.7 \%$ for strains isolated from stool, followed by strains from acute and recurrent UTI with $17.3 \%$ each. The number of adhered bacteria was at least 5 per cell, in which positive strains showed patterns of aggregative and diffuse adherence. No relationship was observed between adherence ability and strain origin.

Eighteen strains with positive adherence and susceptibility to phage infection were selected, in order to assess the effect of phages on bacterial adherence. Phage $\phi E \mathrm{Ec} 1$ and $\phi E \mathrm{Ec} 3$ decreased the adherence in two and three strains, respectively, but phage $\phi E c 4$ was only effective for one strain (Fig. 5). In order to ensure that adherence reduction was a consequence of phage infection, the phage suspension was adjusted to $1 \times 10^{6}$ PFU mL ${ }^{-1}$ at the beginning of the assay. After $2 \mathrm{~h}$ of exposure,

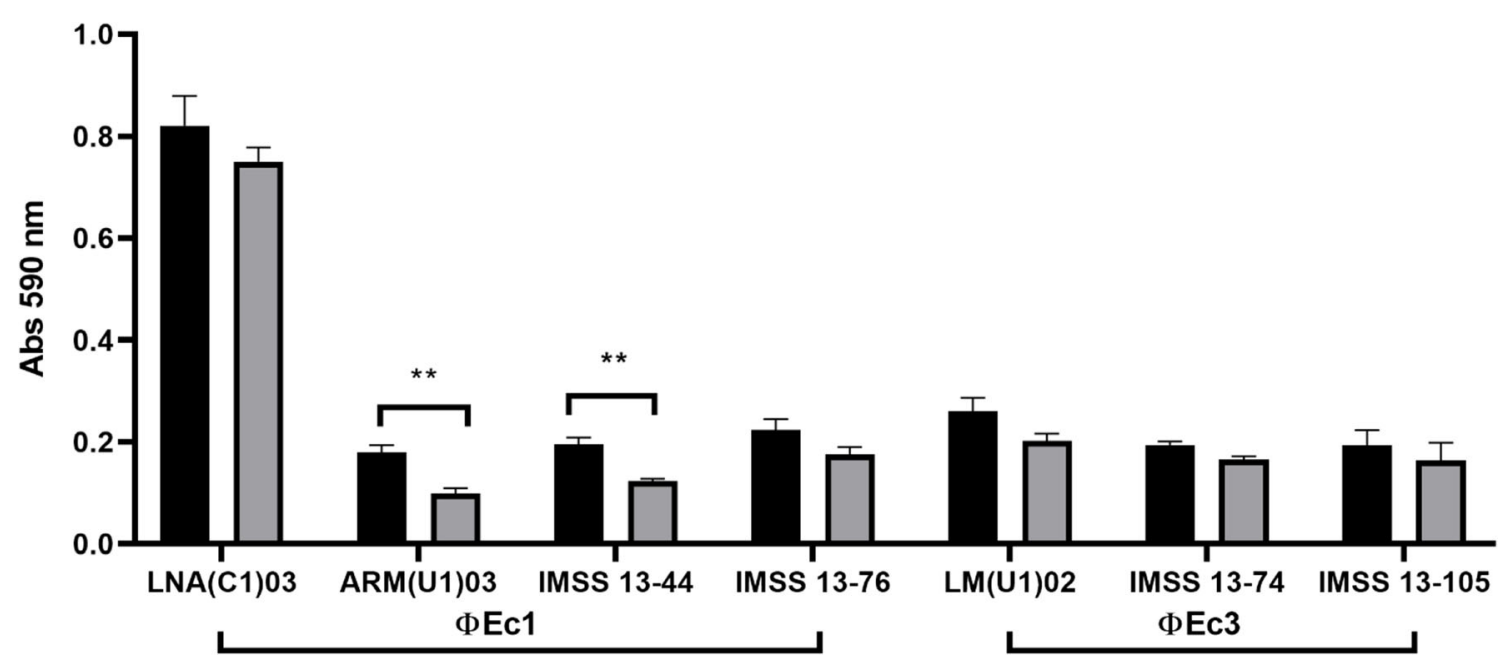

Fig. 4 Phage effect on biofilm production. Biofilm was decreased after $1 \mathrm{~h}$ of exposure. Statistical differences were observed after incubation with phage $\phi \operatorname{Ec} 1(p=0.01)$, whose values were assessed and calculated using Student's t-test with GraphPad Prism 8. Bars represent SEM 
Table 1 Relationship between the production of biofilm, adherence, serogroup, and susceptibility of $E$. coli strains to phage infection

\begin{tabular}{|c|c|c|c|c|c|c|c|c|}
\hline & \multirow[t]{2}{*}{ Strain } & \multirow[t]{2}{*}{ Origin } & \multirow[t]{2}{*}{ Serogroup } & \multirow[t]{2}{*}{ Biofilm } & \multirow[t]{2}{*}{ Adherence } & \multicolumn{3}{|c|}{ Phage susceptibility } \\
\hline & & & & & & $\phi \mathrm{Ec} 1$ & $\phi \mathrm{Ec} 3$ & $\phi \mathrm{Ec} 4$ \\
\hline \multirow[t]{20}{*}{ UPEC serogroups } & CMP(U1)01 & \multirow[t]{6}{*}{ RUTI } & $\mathrm{O} 25$ & - & + & - & + & + \\
\hline & GPB(U2)03 & & $\mathrm{O} 25$ & - & - & - & + & + \\
\hline & $\mathrm{LM}(\mathrm{U} 1) 02$ & & $\mathrm{O} 25$ & Weak & + & - & + & + \\
\hline & RMO(U1)07 & & $\mathrm{O} 25$ & Weak & + & - & + & - \\
\hline & RMR(U5)05 & & $\mathrm{O} 25$ & Weak & $\mathrm{D} / \mathrm{C}$ & - & - & + \\
\hline & PSS(U1)09 & & O6 & Moderate & $\mathrm{D} / \mathrm{C}$ & + & - & - \\
\hline & IMSS 13-20 & \multirow[t]{14}{*}{ aUTI } & $\mathrm{O} 25$ & Moderate & + & - & + & + \\
\hline & IMSS 13-58 & & $\mathrm{O} 25$ & - & + & + & - & - \\
\hline & IMSS 13-64 & & $\mathrm{O} 25$ & - & + & + & - & - \\
\hline & IMSS 13-68 & & $\mathrm{O} 25$ & - & $\mathrm{D} / \mathrm{C}$ & - & + & - \\
\hline & IMSS 13-81 & & $\mathrm{O} 25$ & - & $\mathrm{D} / \mathrm{C}$ & - & + & + \\
\hline & IMSS 13-91 & & $\mathrm{O} 25$ & - & - & + & - & - \\
\hline & IMSS 13-101 & & $\mathrm{O} 25$ & Weak & - & + & - & - \\
\hline & IMSS 13-105 & & $\mathrm{O} 25$ & Weak & - & - & + & + \\
\hline & IMSS 13-119 & & $\mathrm{O} 25$ & Strong & + & + & - & - \\
\hline & IMSS 13-39 & & O75 & - & - & - & - & + \\
\hline & IMSS 13-43 & & O75 & - & $\mathrm{D} / \mathrm{C}$ & - & + & + \\
\hline & IMSS 13-55 & & O75 & - & - & + & - & - \\
\hline & IMSS 13-44 & & O6 & Weak & - & + & - & - \\
\hline & IMSS 13-15 & & $\mathrm{O} 8$ & - & + & - & + & + \\
\hline \multirow[t]{19}{*}{ NON UPEC serogroups } & $\mathrm{AA}(\mathrm{C} 1) 02$ & \multirow[t]{7}{*}{ COM } & NO UPEC & - & - & + & - & - \\
\hline & $\mathrm{CMP}(\mathrm{C} 2) 04$ & & NO UPEC & Moderate & - & + & - & - \\
\hline & CMV(C1)08 & & NO UPEC & Weak & - & + & - & - \\
\hline & LNA(C1)03 & & NO UPEC & Weak & $\mathrm{D} / \mathrm{C}$ & + & - & - \\
\hline & LNA(C1)07 & & NO UPEC & - & - & + & - & - \\
\hline & PSL(C1)05 & & NO UPEC & - & - & + & - & - \\
\hline & RMR(C1)04 & & NO UPEC & - & $\mathrm{D} / \mathrm{C}$ & + & - & - \\
\hline & IMSS 13-4 & \multirow[t]{12}{*}{ aUTI } & NO UPEC & - & - & + & - & - \\
\hline & IMSS 13-5 & & NO UPEC & - & - & + & - & - \\
\hline & IMSS 13-22 & & NO UPEC & - & - & + & - & - \\
\hline & IMSS 13-48 & & NO UPEC & Weak & + & + & - & - \\
\hline & IMSS 13-49 & & NO UPEC & - & + & + & - & - \\
\hline & IMSS 13-74 & & NO UPEC & Weak & $\mathrm{D} / \mathrm{C}$ & - & + & + \\
\hline & IMSS 13-76 & & NO UPEC & Weak & + & + & - & - \\
\hline & IMSS 13-93 & & NO UPEC & - & - & + & - & - \\
\hline & IMSS 13-97 & & NO UPEC & - & - & + & - & - \\
\hline & IMSS 13-99 & & NO UPEC & - & - & + & - & - \\
\hline & IMSS $13-100$ & & NO UPEC & Weak & - & + & - & - \\
\hline & IMSS 13-134 & & NO UPEC & Weak & + & + & - & - \\
\hline \multirow[t]{8}{*}{ Non typeable } & ARM(U2)06 & \multirow[t]{8}{*}{ RUTI } & NT & Weak & + & & & \\
\hline & $\mathrm{EC}(\mathrm{U} 1) 02$ & & NT & - & $\mathrm{D} / \mathrm{C}$ & & & \\
\hline & $\mathrm{EC}(\mathrm{U} 1) 07$ & & NT & Moderate & $\mathrm{D} / \mathrm{C}$ & & & \\
\hline & EGR(U1)05 & & NT & Weak & $\mathrm{D} / \mathrm{C}$ & & & \\
\hline & GPB(U3)09 & & NT & - & - & & & \\
\hline & MCB(U1)01 & & NT & - & + & & & \\
\hline & OGO(U2)05 & & NT & - & - & & & \\
\hline & XZG(U2)01 & & NT & - & + & & & \\
\hline
\end{tabular}


Table 1 (continued)

\begin{tabular}{|c|c|c|c|c|c|c|c|c|}
\hline & \multirow[t]{2}{*}{ Strain } & \multirow[t]{2}{*}{ Origin } & \multirow[t]{2}{*}{ Serogroup } & \multirow[t]{2}{*}{ Biofilm } & \multirow[t]{2}{*}{ Adherence } & \multicolumn{3}{|c|}{ Phage susceptibility } \\
\hline & & & & & & $\phi \mathrm{Ec} 1$ & $\phi \mathrm{Ec} 3$ & $\phi \mathrm{Ec} 4$ \\
\hline & $\mathrm{S}(\mathrm{C} 1) 01$ & $\mathrm{COM}$ & NT & - & + & + & - & - \\
\hline & $\mathrm{TCJ}(\mathrm{C} 1) 04$ & & NT & - & + & + & - & - \\
\hline & TCJ $(\mathrm{C} 1) 08$ & & NT & - & + & + & - & - \\
\hline \multirow[t]{3}{*}{ OR } & ARM(U1)01 & RUTI & OR & - & - & - & + & - \\
\hline & ARM(U1)03 & & OR & Weak & - & + & + & - \\
\hline & CMV(U1)03 & & OR & - & - & + & - & - \\
\hline
\end{tabular}

RUTI: E. coli isolates from recurrent UTI; aUTI: E. coli isolate from acute UTI; COM: gut commensal strain; NT: Non Typeable, OR: rough strain, D/C: bacteria promoted the detachment of the monolayer HEp-2 cells

phages were quantified and their titers showed an increase of at least $1 \log$ (Fig. 6), which was consistent in all microscopic observations performed after phage infection.

\section{Discussion}

As we live in the antibiotic era, it was easy to assume that these agents would be permanently available in the drug arsenal. However, the overuse and misuse of antibiotics has been accompanied by the rapid emergence of antibiotic-resistant
Fig. 5 Phage effect on bacterial adherence. UPEC adherence was decreased after $1 \mathrm{~h}$ of phage infection. Effect of phage $\phi E c 1:$ a control assay HEp-2 cells-UPEC, b bacterial adherence after phage exposure. Effect of phage $\phi E c 3: \mathbf{c}$ bacterial adherence without phages, $\mathbf{d}$ phage $\phi \mathrm{Ec} 3$ almost eliminated all attached bacteria. $\mathbf{e}$ Control Hep-2 cells

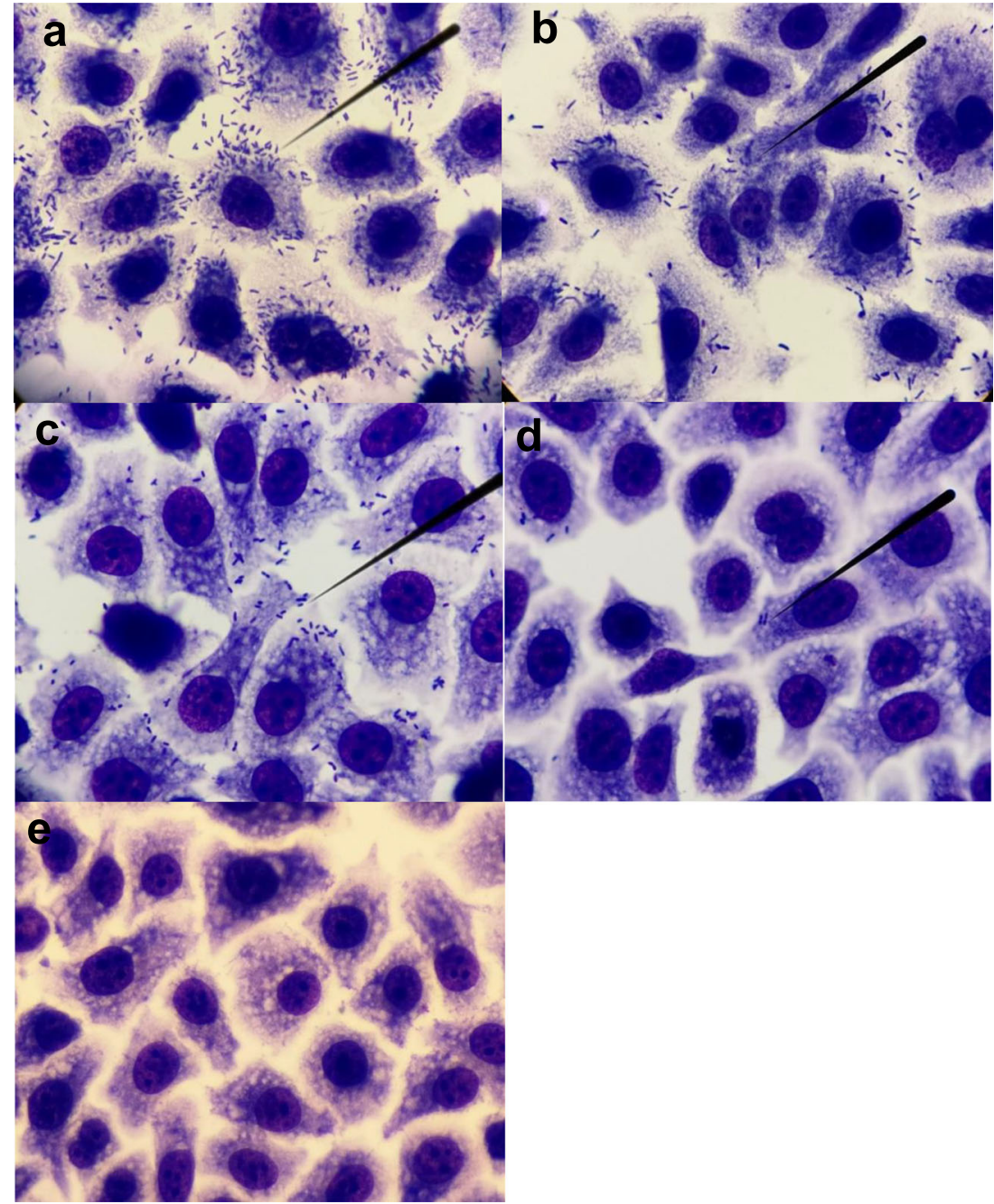


Fig. 6 Phages effect on UPEC attached to HEp-2 cells. Phage titers before and after UPEC infection. Higher PFU numbers were recovered after initial $E$. coli infection, whose values were assessed and calculated using ANOVA with GraphPad Prism 8 Bars represent SEM



bacteria (Morehead and Scarbrough 2018). Antibiotic resistance is life-threatening, which raises mortality rates, increases human suffering, extends hospitalization periods, and decreases productivity, along with the economic burden that takes a staggering toll in the health care system (Santoro et al. 2020; Serra-Burriel et al. 2020).

The worldwide emergence of MDR bacterial strains has created the need for implementing measures to control these threats. As a consequence, lytic phages have reemerged as a promising alternative for the control of pathogenic bacteria (Kakasis and Panitsa 2019; Ghosh et al. 2019). Because phage therapy is under study as a therapeutic approach, further development of this method requires biological characterization of phages, such as their host specificity and adaptation to their bacterial hosts (Amarillas et al. 2017; Sváb et al. 2018; Hyman 2019).

From the six wastewater sample locations, 12 phages were originally isolated, and only three were further characterized. Selected phages displayed the basic features to classify them into two different morphologies. The morphology of phage $\phi E c 1$ resembles the Myoviridae family, distinguished by an extraordinarily large icosahedral head, which contracts to half of its original length upon infection. In contrast, the morphology of phages $\phi E \mathrm{E} 3$ and $\phi E \mathrm{E} 4$ resemble the Siphoviridae family, whose members have icosahedral heads and noncontractile and flexible tails (King et al. 2012). Previous studies have demonstrated that the $E$. coli-infecting phages usually belong to the Myoviridae family. However, a recent study demonstrated that $E$. coli-infecting phages, previously isolated from Danish wastewater, belonged to seven different families, such as Myoviridae, Siphoviridae, Podoviridae, Drexlerviridae, Chaseviridae, Autographviridae, and Microviridae (Olsen et al. 2020). Despite the wide diversity of $E$. coli-infecting phages, many studies are restricted to the isolation and characterization of phages for food industry applications (Khalatbari-Limaki et al. 2020). Moreover, limited information is available on the use of phages against MDR UPEC strains. In this study, the three phages showed specificity for $E$. coli clinical isolates, as no infectivity was detected for Salmonella, Pseudomonas, Yersinia, Klebsiella, Shigella, and Staphylococcus.

Phage $\phi E c 1$ showed a broader range through the $E$. coli strain groups (acute, recurrent, and stool cultures). Likewise, phage $\phi E c 1$ lysed $23 \%$ (35/150) of clinical isolates and the group with the highest susceptibility was acute strains with $51 \%(18 / 35)$. Most of the lysed strains belonged to nonUPEC serogroups including non-typeable (NT) and "O" rouge (OR) strains. Although phages $\phi E c 3$ and $\phi E c 4$ lysed fewer strains than did $\phi E c 1$, their effect was restricted to UTI (acute and recurrent) strains. Specifically, the serogroup sensitive to the phages wasO25, which is one of the most frequently isolated serogroups (17\%) in Mexico, followed by $\mathrm{O} 1$ (10\%), O8 (9\%), O6 (4\%), and O75 (3\%) (Belmont-Monroy et al. 2017). These serogroups have also been associated up to $60 \%$ with extensively drug-resistant $E$. coli due to the production of extended-spectrum $\beta$-lactamases (Hernández-Chiñas et al. 2019). Therefore, phages $\phi E c 3$ and $\phi E c 4$ with specific UPEC spectrum can be useful for therapy, which represent an alternative for the treatment against infections caused by virulent MDR UPEC serogroups.

Genome restriction analyses allowed us to indirectly assume genomic differences among the three phages. $\phi E \mathrm{E} 1 \mathrm{ge}-$ nome showed fewer bands in all the restriction assays, which suggests its relative resistance against $E$. coli RM system (Flodman et al. 2019). This feature correlates with its broader range of infectivity and lysis against acute and recurrent UPEC strains as well as E. coli stool isolates. The patterns shown by $\phi E c 1$ were different than those presented by the other two phages. Different fragment patterns were identified in $\phi E c 3$ and $\phi E c 4$ restricted genomes compared with $\phi E c 1$. However, there are clear pattern differences between $\phi E c 3$ and $\phi E c 4$. Shared bands and unique bands between $\phi E c 3$ 
and $\phi E c 4$ suggest a closer phylogenetic relation between them when compared to $\phi E c 1$ (López-Cuevas et al. 2011). Genomic restriction of both phages correlated with their narrower range against the three groups of $E$. coli tested, as both phages only infected UPEC strains.

To further demonstrate differences among phages, protein composition was analyzed by SDS-PAGE. One main protein of $50 \mathrm{kDa}$ was detected in phage $\phi \mathrm{Ec} 1$. Phages belonging to the Myoviridae family commonly show two major structural proteins ranging from 50 to $55 \mathrm{kDa}$. These proteins are related to the major tail sheath proteins, whereas proteins with a molecular mass of around $23-25 \mathrm{kDa}$ are related to the capsid protein (O'Flaherty et al. 2004; Boulanger 2009). For phages $\phi \mathrm{Ec} 3$ and $\phi \mathrm{Ec} 4$, a protein of $36-37 \mathrm{kDa}$ was detected. Previous studies have reported that the main proteins of the Siphoviridae family are found in a range from 41 to $51 \mathrm{kDa}$ (Zhang et al. 2006; López-Cuevas et al. 2011). Additionally, a protein of $11 \mathrm{kDa}$ was detected in $\phi \mathrm{Ec} 3$ and $13 \mathrm{kDa}$ in $\phi \mathrm{Ec} 4$. SDS-PAGE protein analysis indicated clear composition differences among the phages, reinforcing the idea of their phylogenetic difference.

Adherence and biofilm production are key in UTI pathogenesis as both features play a crucial role in the first stages of UTIs development, and evolution toward recurrence (McLellan and Hunstad 2016). Biofilms allow E. coli to grow in a hostile environment, acting as a barrier that prevents the passage of antibiotics as well as avoiding the effect of the immune system (Hufnagel et al. 2015). The three groups of tested strains showed very low biofilm formation frequencies, with $32 \%(n=48)$ of the isolates being biofilm producers. This percentage is closer to the results obtained by Behzadi et al. (2020), who isolated 250 E. coli strains from clean-catch urine samples from patients with laboratory-confirmed UTIs. The role of biofilm formation in colon-residing strains highlights its participation in the maintenance of the commensal microbiota, protecting it from the colonization of atypical bacteria (Da Re et al. 2013). It is important to note that the origin of the strains did not condition biofilm formation. Since colonresiding strains are the main reservoir for UTI development, another explanation for low biofilm production resides in sugars of the intestinal mucosa, which are essential in biofilm formation (Sicard et al. 2018).

The isolated phages decreased biofilm formation after a short exposure time; however, this effect was not evident in all the tested strains. In contrast, a previous study revealed that the effect of phage vB_EcoP-EG1 in the biofilm biomass reduction was $60 \%$ (Gu et al. 2019); however, in comparison with our study, the effect was evaluated $24 \mathrm{~h}$ after phage exposure. In our study, the effect can be explained due to bacterial metabolic state having been diminished during biofilm formation. Probably, this reduction does not favor the productive infection of the tested phages, and phage replication depends on the biosynthetic machinery of the host bacterium. Another point to be considered is that while there are reports of the use of depolymerases by phages belonging to the order of the Caudovirales (Fernandes and São-José 2018; Liu et al. 2019), the products derived from bacterial lysis stimulate the increase of a crystalline matrix and as a result increase adherence and resistance to desiccation (Secor et al. 2015). In order to improve biofilm study model, constant replacement of the medium could be subjected, thus eliminating the cellular remnants derived from the initial phage lysis, preventing them from being a part of the extracellular matrix.

The adherence process reflects the strategies followed by the bacterium adaptation to the different niches that it can inhabit. In the case of strains from stool cultures, it ensures the acquisition of nutrients and permanence in the intestinal tract. On the other hand, in UPEC UTI strains, it facilitates colonization and persistence in the urinary tract, as well as resistance to antimicrobials and evasion of the immune response, ensuring their survival (Conte et al. 2016; Cordeiro et al. 2016). The isolated phages showed the ability to decrease the number of bacteria in adherence assays. However, this reduction was not evident in all tested strains but only in six of them. We assume that the behavior involves factors related with the host-like metabolic state, presence of phagereceptors, or bacterial reorganization. Furthermore, there are other factors inherent to phages, such as burst size, absorption rate, and lysis time (Lindberg et al. 2014). This is the first insight exploring phage effect against UPEC adherence, and unfortunately there is no data to directly compare with our results. However, the data presented here shows a biological effect on the adhered bacteria, which showed the expected relationship of the increase in the number of phages, with the reduced number of adhered bacteria in the HEp-2 cell line.

The goal is to produce phage mixtures or identify phage proteins with a biological effect against MDR UPEC (Tagliaferri et al. 2019). However, it is important to clarify that despite the success of this trial, limitations such as the emergence of bacterial resistance after being constantly subjected to phages should not be ignored. Studies like this will expand our phage characteristics knowledge, pivotal toward in vivo studies and to ensure its safety and efficacy for human treatment (Oechslin 2018).

In conclusion, this is the first study related to phage identification in Mexico and their potential use against MDR UPEC. Although no relationship was observed between MDR and phage susceptibility, it was demonstrated that identified phages had a specific effect against E. coli. In fact, phages $\phi E c 3$ and $\phi E c 4$ were specific for UPECs from acute and recurrent UTIs. We also demonstrated that phages decreased biofilm formation. We highlight the phage effect against UPEC adherence on HEp-2 cells as the first report. $\phi \mathrm{Ec} 3$ and $\phi \mathrm{Ec} 4$ are the first phages reported in Mexico with potential use against UTIs. 
Supplementary Information The online version contains supplementary material available at https://doi.org/10.1007/s00253-021-11432-6.

Acknowledgements We thank Hospital Infantil de México Federico Gómez, Posgrado en Biomedicina y Biotecnología Molecular, ENCB, Instituto Politécnico Nacional, Dirección de Formación Académica, Departamento de Fortalecimiento Académico, Programa de Becas Postdoctorales, Universidad Nacional Autónoma de México. EG-V thanks CONACyT, Mexico for PhD and postdoctoral fellowship. RMR-A and GA-O are recipients of Comisión de Operación y Fomento de Actividades Académicas (COFAA-IPN) and Programa de Estímulo al Desempeño Docente (EDD-IPN) fellowships. JLB acknowledges the support from the Economy and Knowledge Department of the Catalan Government through Consolidated Research Group (ICRA-ENV 2017 SGR 1124), as well as from the CERCA program.

Authors' contributions EG-V and GERM: conceptualization, methodology, investigation, writing-original draft. JM-L, RMR-A, and GA-O: conceptualization, funding acquisition, supervision, writing-review and editing. LB-M and YO-G: methodology. JLB, UH-C, and CAE-C: writing-review and editing. All authors agreed to the final version of the manuscript.

Funding This work was supported by PAPIIT IN220717 and CONACyT grant A1S-17336, and by the Instituto Politécnico Nacional (IPN), through SIP-IPN grants 20202136, and 20201438.

Data availability The datasets generated during and/or analyzed during the current study are available from the corresponding author on reasonable request.

\section{Declarations}

Ethics approval and consent to participate This article does not contain any studies with human participants or animals performed by any of the authors.

Conflict of interest The authors declare no conflict of interest.

\section{References}

Adriaenssens E, Brister JR (2017) How to name and classify your phage: an informal guide. Viruses 9:70. https://doi.org/10.3390/v9040070

Ahumada-Cota RE, Hernández-Chiñas U, Milián-Suazo F, ChávezBerrocal ME, Navarro-Ocaña A, Martínez-Gómez D, PatiñoLópez G, Salazar-Jiménez EP, Eslava CA (2020) Effect and analysis of bacterial lysates for the treatment of recurrent urinary tract infections in adults. Pathogens 2:102. https://doi.org/10.3390/ pathogens 9020102

Amarillas L, Rubí-Rangel L, Chaidez C, González-Robles A, Lightbourn-Rojas L, León-Félix J (2017) Isolation and characterization of phiLLS, a novel phage with potential biocontrol agent against multidrug-resistant Escherichia coli. Front Microbiol 8: 1355. https://doi.org/10.3389/fmicb.2017.01355

Behzadi P, Urbán E, Gajdács M (2020) Association between biofilmproduction and antibiotic resistance in uropathogenic Escherichia coli (UPEC): an in vitro study. Diseases 8:17. https://doi.org/10. 3390/diseases 8020017
Belmont-Monroy L, Ribas-Aparicio RM, Navarro-Ocaña A, ManjarrezHernández HA, Gavilanes-Parra S, Aparicio-Ozores G, CauichSánchez PI, Garza-Ramos U, Molina-López J (2017) Characterization of Escherichia coli causing community acquired urinary tract infections in Mexico City. Diagn Microbiol Infect Dis 87:193-195. https://doi.org/10.1016/j.diagmicrobio.2016.11.006

Boulanger P (2009) Methods and protocols, volume 2: molecular and applied aspects, vol 502. 2009 Humana Press, a part of Springer Science+Business Media. https://doi.org/10.1007/978-1-60327565-1

Chibeu A, Lingohr EJ, Masson L, Manges A, Hardel J, Hans-W A, Kropisnki AM, Boerlin P (2012) Bacteriophages with the ability to degrade uropathohgenic Escherichia coli biofilms. Viruses 4: 471-487. https://doi.org/10.3390/v4040471

Conte MP, Aleandri M, Marazzato M, Conte AL, Ambrosi C, Nicoletti M, Longhi C (2016) The adherent/invasive Escherichia coli strain LF82 invades and persists in human prostate cell line RWPE-1, activating a strong inflammatory response. Infect Immun 11:31053113. https://doi.org/10.1128/IAI.00438-16

Cordeiro MA, Werle CH, Milanez GP, Yano T (2016) Curli fimbria: an Escherichia coli adhesin associated with human cystitis. Braz J Microbiol 2:414-416. https://doi.org/10.1016/j.bjm.2016.01.024

Da Re S, Valle J, Charbonnel N, Beloin C, Latour-Lambert P, Faure P, Ghigo JM (2013) Identification of commensal Escherichia coli genes involved in biofilm resistance to pathogen colonization. PLoS One 5:e61628. https://doi.org/10.1371/journal.pone.0061628

Fernandes S, São-José C (2018) Enzymes and mechanisms employed by tailed bacteriophages to breach the bacterial cell barriers. Viruses 8: 396. https://doi.org/10.3390/v10080396

Flodman K, Tsai R, Xu MY, Corréa IR, Copelas A, Lee Y-J, Xu M-Q, Wigele P, Xu S-y (2019) Type II restriction of bacteriophage DNA with 5 hmdU-derived base modifications. Front Microbiol 10:584. https://doi.org/10.3389/fmicb.2019.00584

Foxman B (2010) The epidemiology of urinary tract infection. Nat Rev Urol 7:653-660. https://doi.org/10.1038/nrurol.2010.190

Foxman B (2014) Urinary tract infection syndromes: occurrence, recurrence, bacteriology, risk factors, and disease burden. Infect Dis Clin N Am 28:1-13. https://doi.org/10.1016/j.idc.2013.09.003

Ghosh C, Sarkar P, Issa R, Haldar J (2019) Alternatives to conventional antibiotics in the era of antimicrobial resistance. Trends Microbiol 27:323-338. https://doi.org/10.1016/j.tim.2018.12.010

Gordillo-Altamirano FL, Barr JJ (2019) Phage therapy in the postantibiotic era. Clin Microbiol Rev 2:e00066-e00018. https://doi. org/10.1128/CMR.00066-18

Gu Y, Xu Y, Xu J, Yu X, Huang X, Liu G, Liu X (2019) Identification of novel bacteriophage vB EcoP-EG1 with lytic activity against planktonic and biofilm forms of uropathogenic Escherichia coli. Appl Microbiol Biotechnol 103:315-326. https://doi.org/10.1007/ s00253-018-9471-x

Hall CW, Mah TF (2017) Molecular mechanism of biofilm-based antibiotic resistance and tolerance in pathogenic bacteria. FEMS Microbiol Rev 3:276-301. https://doi.org/10.1093/femsre/fux010

Hans WA (2009) Basic Phage Electron Microscopy. In: Clokie RJM, Kropinski AM (eds) Bacteriophages methods and protocols, vol 1, 1st edn. Humana press, New York, pp 113-126. https://doi.org/10. 1007/978-1-

Hernández-Chiñas U, Pérez-Ramos A, Belmont-Monroy L, ChávezBerrocal ME, González-Villalobos E, Navarro-Ocaña A, Eslava CA, Molina-Lopez J (2019) Characterization of auto-agglutinating and non-typeable uropathogenic Escherichia coli strains. J Infect Dev Ctries 13:465-472. https://doi.org/10.3855/jidc.11098 
Hufnagel DA, Depas WH, Chapman MR (2015) The biology of the Escherichia coli extracellular matrix. Microbiol Spectr 3. https:// doi.org/10.1128/microbiolspec.MB-0014-2014

Hyman P (2019) Phages for phage therapy: isolation, characterization, and host range breadth. Pharmaceuticals 12:35. https://doi.org/10. 3390/ph12010035

Jamal M, Bukhari SMAUS, Andleeb S, Ali M, Raza S, Nawaz MA, Hussain T, Rahman SU, Shah SSA (2019) Bacteriophages: an overview of the control strategies against multiple bacterial infections in different fields. J Basic Microbiol 59:123-133. https://doi.org/10. $1002 /$ jobm. 201800412

Kakasis A, Panitsa G (2019) Bacteriophage therapy as an alternative treatment for human infections. A comprehensive review. Int $\mathrm{J}$ Antimicrob Agents 53:16-21. https://doi.org/10.1016/j.ijantimicag. 2018.09.004

Karigoudar RM, Karigoudar MH, Wavare SM, Mangalgi SS (2019) Detection of biofilm among uropathogenic Escherichia coli and its correlation with antibiotic resistance pattern. J Lab Physicians 11: 17-22. https://doi.org/10.4103/JLP.JLP 9818

Khalatbari-Limaki S, Hosseinzadeh S, Shekarforoush SS, Berizi E (2020) The morphological and biological characteristics of a virulent PI phage isolated from slaughterhouse sewage in Shiraz, Iran. Iran J Microbiol 12:616-624. https://doi.org/10.18502/ijm.v12i6.5037

King AMQ, Adams MJ, Carstens EB, Lefkowitz EJ (2012) Virus taxonomy: ninth report of the International Committee on Taxonomy of Viruses. Elsevier, Amsterdam

Kot B (2019) Antibiotic resistance among uropathogenic Escherichia coli. Pol J Microbiol 68:403-415. https://doi.org/10.33073/pjm2019-048

Kropinsky AM, Mazzoco A, Waddell TE, Lingohr E, Jhonson RP (2009) Enumeration bacteriophages by double agar overlay plaque assay. In: Clokie RJM, Kropinski AM (eds) Bacteriophages Methods and Protocols, vol 1, 1st edn. Humana press, New York, pp 69-76. https://doi.org/10.1007/978-1-60327-164-6

Kutter E (2009) Phage host range and efficiency of plating. In: Clokie RJM, Kropinski AM (eds) Bacteriophages Methods and Protocols, vol 1, 1st edn. Humana press, New York, pp 141-151. https://doi. org/10.1007/978-1-

Li D, Liu B, Chen M, Guo D, Guo X, Liu F, Feng L, Wang L (2010) A multiplex PCR method to detect 14 Escherichia coli serogroups associated with urinary tract infections. J Microbiol Methods 82: 71-77. https://doi.org/10.1016/j.mimet.2010.04.008

Lindberg HM, McKean KA, Wang IN (2014) Phage fitness may help predict phage therapy efficacy. Bacteriophage 4:e964081. https:// doi.org/10.4161/21597073.2014.964081

Liu Y, Mi Z, Mi L, Huang Y, Li P, Liu H, Gao Z (2019) Identification and characterization of capsule depolymerase Dpo48 from Acinetobacter baumannii phage IME200. PeerJ 7:e6173. https:// doi.org/10.7717/peerj.6173

López-Cuevas O, Castro-del Campo N, León-Félix J, González-Robles A, Chaidez C (2011) Characterization of bacteriophages with a lytic effect on various Salmonella serotypes and Escherichia coli O157: H7. Can J Microbiol 57:1042-1051. https://doi.org/10.1139/w11099

Magana M, Sereti C, Ioannidis A, Mitchell CA, Ball AR, Magiorkinis E, Chatzipanagiotou S, Hamblin MR, Hadjifrangiskou M, Tegos GP (2018) Options and limitations in clinical investigation of bacterial biofilms. Clin Microbiol Rev 31:E00084-E00016. https://doi.org/ 10.1128/CMR.00084-16

Mann R, Mediati DG, Duggin IG, Harry EJ, Bottomley AL (2017) Metabolic adaptations of uropathogenic E. coli in the urinary tract. Front Cell Infect Microbiol 7:241. https://doi.org/10.3389/fcimb. 2017.00241
Mathewson JJ, Cravioto A (1989) HEp-2 cell adherence as an assay for virulence among diarrheagenic Escherichia coli. J Infect Dis 6: 1057-1060. https://doi.org/10.1093/infdis/159.6.1057

Mazzocco A, Wadell TE, Lingohr E, Johnson P (2009) Enumeration of bacteriophages using small drop plaque assay system. In: Clokie RJM, Kropinski AM (eds) Bacteriophages Methods and Protocols, vol 1, 1st edn. Humana press, New York, pp 81-85. https://doi.org/ 10.1007/978-1-60327-164-6

McLellan LK, Hunstad DA (2016) Urinary tract infection: pathogenesis and outlook. Trends Mol Med 11:946-957. https://doi.org/10.1016/ j.molmed.2016.09.003

Morehead MS, Scarbrough C (2018) Emergence of global antibiotic resistance. Prim Care 45:467-484. https://doi.org/10.1016/j.pop.2018. 05.006

O'Flaherty S, Coffey A, Edwards R, Meaney W, Fitzgerald GF, Ross RP (2004) Genome of staphylococcal phage K: a new lineage of Myoviridae infecting gram-positive bacteria with a low $\mathrm{G}+\mathrm{C}$ content. J Bacteriol 9:2862-2871. https://doi.org/10.1128/JB.186.9. 2862-2871.2004

Oechslin F (2018) Resistance development to bacteriophages occurring during bacteriophage therapy. Viruses 7:351. https://doi.org/10. 3390/v10070351

Olsen NS, Forero-Junco L, Kot W, Hansen LH (2020) Exploring the remarkable diversity of culturable Escherichia coli phages in the Danish wastewater environment. Viruses 12:986. https://doi.org/ 10.3390/v12090986

Principi N, Silvestri E, Esposito S (2019) Advantages and limitations of bacteriophages for the treatment of bacterial infections. Front Pharmacol 10:513. https://doi.org/10.3389/fphar.2019.00513

Sambrook J, Russell DW (2001) Molecular cloning: a laboratory manual, vol 2. Cold Spring Harbor Laboratory Press, New York

Santoro A, Franceschini E, Meschiari M, Menozzi M, Zona S, Venturelli C, Digaetano M, Rogati C, Guaraldi G, Paul M, Gyssens IC, Mussini C (2020) Epidemiology and risk factors associated with mortality in consecutive patients with bacterial bloodstream infection: impact of MDR and XDR bacteria. Open Forum Infect Dis 7 : ofaa461. https://doi.org/10.1093/ofid/ofaa461

Secor PR, Sweere JM, Michaels LA, Malkovskiy AV, Lazzareschi D, Katznelson E, Rajadas J, Birnbaum ME, Arrigoni A, Braun KR, Evanko SP, Stevens DA, Kaminsky W, Singh PK, Parks WC, Bollyky PL (2015) Filamentous bacteriophage promote biofilm assembly and function. Cell Host Microbe 5:549-559. https://doi.org/ 10.1016/j.chom.2015.10.013

Serra-Burriel M, Keys M, Campillo-Artero C, Agodi A, Barchitta M, Gikas A, Palos C, López-Casasnovas G (2020) Impact of multidrug resistant bacteria on economic and clinical outcomes of healthcare-associated infections in adults: Systematic review and meta-analysis. PLoS One 15:e0227139. https://doi.org/10.1371/ journal.pone.0227139

Sicard JF, Vogeleer P, Le Bihan G, Rodriguez Olivera Y, Beaudry F, Jacques M, Harel J (2018) N-Acetyl-glucosamine influences the biofilm formation of Escherichia coli. Gut Pathog 10:26. https:// doi.org/10.1186/s13099-018-0252-y

Stepanović S, Vuković D, Hola V, Di Bonaventura G, Djukić S, Cirković I, Ruzicka F (2007) Quantification of biofilm in microtiter plates: overview of testing conditions and practical recommendations for assessment of biofilm production by Staphylococci. APMIS 8:891899. https://doi.org/10.1111/j.1600-0463.2007.apm_630.x

Subaschandrabose S, Mobley HLT (2015) Virulence and fitness determinants of Uropathogenic Escherichia coli. Microbiol Spectr 3:1-32. https://doi.org/10.1128/microbiolspec.UTI-0015-2012

Sváb D, Falgenhauer L, Rohde M, Szabó J, Chakraborty T, Tóth I (2018) Identification and characterization of T5-Like bacteriophages 
representing two novel subgroups from food products. Front Microbiol 9:202. https://doi.org/10.3389/fmicb.2018.00202

Tacconelli E, Magrini M (2020) Global priority list of antibiotic-resistant bacteria to guide research, discovery, and development of new antibiotics. www.who.int/medicines/publications/WHOPPLShort Summary_25Feb-ET_NM_WHO (accessed on 9 June 2020).

Tagliaferri TL, Jansen M, Horz HP (2019) Fighting pathogenic bacteria on two fronts: phages and antibiotics as combined strategy. Front Cell Infect Microbiol 9:22. https://doi.org/10.3389/fcimb.2019. 00022

Tamadonfar KO, Omattage NS, Spaulding CN, Hultgren SJ (2019) Reaching the end of the line: urinary tract infections. Microbiol Spectr 7(3):BAI-0014-2019. https://doi.org/10.1128/microbiolspec. BAI-0014-2019

Terlizzi EM, Gribaudo G, Maffei ME (2017) Uropathogenic Escherichia coli (UPEC) infections: virulence factors, bladder responses, antibiotic, and non-antibiotic antimicrobial strategies. Front Microbiol 8:1566. https://doi.org/10.3389/fmicb.2017.01566

Zhang X, Kong J, Qu Y (2006) Isolation and characterization of a Lactobacillus fermentum temperate bacteriophage from Chinese yogurt. J Appl Microbiol 101:857-863. https://doi.org/10.1111/j. 1365-2672.2006.03007.x

Zhao J, Zhang Z, Tian C, Chen X, Hu L, Wei X, Li H, Lin W, Jiang A, Feng R, Yuan J, Yin Z, Zhao X (2019) Characterizing the biology of lytic bacteriophage vB_EaeM_ $\varphi$ Eap-3 infecting multidrug-resistant Enterobacter aerogenes. Front Microbiol 10:420. https://doi.org/10. 3389/fmicb.2019.00420

Publisher's note Springer Nature remains neutral with regard to jurisdictional claims in published maps and institutional affiliations. 